\title{
From the new editors
}

WE FACE the task of editing ET with a mixture of trepidation and excitement. Trepidation because our editorial efforts will follow those of Tom McArthur who has been editor of English Today since its inception, and who has made such an immense contribution to scholarship in this field. Indeed, it is no small measure of Tom's stature and capabilities that it has been decided at least three new editors are required to take his place. We have large shoes to fill.

At the same time, this is an exciting challenge for each of us. The spread of English worldwide has been and continues to be one of the most important stories of the contemporary age. It is a phenomenon of interest not only to linguists but to academics across multiple disciplines, as well as a much wider audience of educators, teachers, communicators, and many others with an interest in language and language matters. It is also a story that needs to be told from a range of different viewpoints.

It is a mark of the success of ET over the last twenty-two years that the journal has included a fascinating variety of perspectives: linguists, grammarians, lexicographers, broadcasters, and publishers. Part of the story (as we can see from the latest index, included in this double issue) has been concerned with the geographical spread of the language. In ET, the coverage of world Englishes has included so-called 'established' varieties in countries such as Britain, the USA, and Australia, the 'New Englishes' of Africa and Asia, as well as English across Europe, the former Soviet Union, and China. At another level, articles on questions of structure and usage have ranged from lexicography, syntax, and corpus linguistics to international advertising, digital communication, and electronic communication. English Today has been able to give space to all this and much more in inimitable fashion.

In addition, Tom McArthur has been unfailing in his support of young (and not-so-young) contributors from the developing world, who have often provided immediate and first-hand accounts of English in societies from Nigeria to Macedonia, and from Cameroon to Uzbekistan. At a personal as well as a professional level, he has shown unstinting generosity to new scholars in the field from many different 
backgrounds. In this, as in many other aspects of his editorial work, he has given us an exemplary model to follow. We do indeed have large shoes to fill, but with the support of the readership, as well as the enthusiasm of scholars in the field, we shall endeavour to do our best. We shall also be looking for some thick socks.

Kingsley Bolton, David Graddol, and

Raj Mesthrie

Kingsley Bolton is Professor of English Linguistics at Stockholm University. His major research interests include sociolinguistics and the study of English worldwide. Recent publications include Hong Kong English: Creativity and Autonomy (ed. Hong Kong University Press 2002),

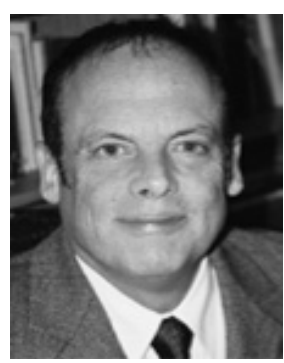
Chinese Englishes: A Sociolinguistic History (Cambridge University Press, 2003), World Englishes: Critical Concepts in Linguistics (with Braj B. Kachru, Routledge, 2006), Asian Englishes (with Braj B. Kachru, Routledge, 2007).

David Graddol is an independent researcher and publisher who has published widely on English linguistics and global English, and lectures on such topics worldwide. His publications include English: History, Diversity and Change (with Dick Leith and Joan Swann, Routledge 1996), The Future of English? (1997, The English Company/ The British Council), English in a Changing World (with Ulrica Meinhof, AILA, 1999), and English Next (2006, The English Company/The British Council).

Rajend Mesthrie is Professor of Linguistics in the Department of English at the University of Cape Town, with research interests in sociolinguistics, and language contact and variation in South Africa. His publications include

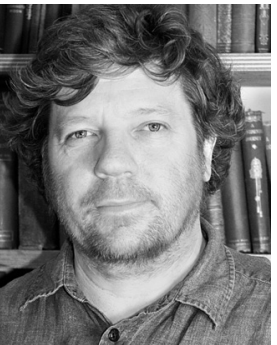
English in Language Shift: the History, Structure and Sociolinguistics of South African Indian English (Cambridge University Press, 1992), Language in South Africa (ed., Cambridge University Press, 2002), and Introducing Sociolinguistics (Edinburgh University Press, 2000). 